\title{
WHAT DOES FINANCIAL INTERMEDIATION THEORY TELL US ABOUT FINTECHS?
}

Technology and the widespread usage of internet have gradually changed the design and delivery of several banking services. Internet and mobile banking has become the self-service delivery channel, while new information technologies have lowered the barrier of entering the finance industry.

These changes have fueled the entrance of new type of banks and financial institutions in the financial sector. The common characteristics of these new entrants that they adopted an internet-only strategy and rely on online and mobile networks to meet the customers' transaction and financial needs. The rise of new internet-based players is a global trend, reaching developed and developing economies alike. This study discusses the role of these new entrants in the financial market in the context of the financial intermediation literature. It focuses on two particular segments of the Fintech sector: online marketplace lenders and neo-banks. The main questions the study is addressing is what role Fintechs are playing in financial intermediation and whether these players are complement or compete with commercial banks. Are these players disintermediating commercial banks or do they play a rather supplementary role in the financial intermediation?

Keywords: FinTech, financial technology, financial intermediation, competition

$\mathrm{T}$ he proliferation and advancement of technology, especially the use of the internet and mobile phones, is leading to fundamental changes in how companies interact with customers. Technology and the widespread usage of internet have gradually changed the design and delivery of several banking services. Internet and mobile banking has become the self-service delivery channel that allows banks to provide information and offer services to their customers with more convenience. At the same time, the ubiquity of the internet and new information technologies have lowered the barrier of entering the finance industry by reducing the initial investment and the transaction costs.

These changes have fueled the entrance of new type of financial intermediaries, Fintechs in the financial sector. The common characteristics of these new entrants that they adopted an internet-only strategy having little or even no branch system and relying on other networks - mainly internet and mobile - to meet the majority of customers' transaction and financial needs. The rise of new internet-based players is a global trend, reaching developed and developing economies alike.

The question arises whether do Fintechs have the potential to compete with, or replace them in the financial intermediation. This study aims to discuss the role of these new entrants in the financial market in the context of the financial intermediation literature. The paper focuses on two segments of the Fintech sector: online marketplace lenders and neo-banks. While online marketplace lenders aiming to disintermediate traditional banks in credit process, neo-are banks providing deposit services for customers in a low-cost operating model. Both types of entrants claim to bring ambitions changes for the financial industry: to 'disrupt' long-established traditional commercial banking business models. Although these players have gained significant media attention recently, the academ- ic literature to understand the role and operation of these players is limited.

The main question the paper is addressing is what role online marketplace lenders and neo-banks are playing in the economy from a financial intermediation theory perspective. Are these players disintermediating commercial banks or do they play a rather supplementary role in the financial intermediation?

The structure of this paper is the following: First, it introduces the foundations of the literature of financial intermediation theory and reflects on the implications of technology and Fintech innovation on the financial intermediation. The main purpose of the chapter is to get an understanding what the fundamental role of banks in the economy is. In the second section, the paper infers the key differentiating factors with respect to the function of banks versus other financial intermediaries. In the last section, the paper assesses whether the reduction of transaction costs and information asymmetries caused by the development of information technologies create opportunity for new type of financial intermediaries and business models. The question addressed by this section is whether online marketplace lenders and neo-banks are able to compete with banks and potentially replace them or are they rather complementary to the existing financial intermediation activity of traditional banks.

\section{The role of banks and the implication of technology}

This section focuses on to summarize the core literature on the existence of financial intermediaries. It is claimed that banks exist to solve or reduce market imperfections, such as: differences in the preferences of lenders and borrowers (in terms of size, maturity, liquidity, risk), presence of transaction costs, shocks in consumers' consumption 
and asymmetric information (which gives rise to both adverse selection and moral hazard). Standard textbooks explain banks as an institution that core operations consist of granting loans by deposits from the public (Rochet - Freixas, 2008; Greenbaum - Thakor, 2007). This definition refers to the core activity of commercial banks, namely the simultaneous acceptance of deposits and offering of loans, which distinguishes them from other financial intermediaries. However, banks typically conduct a broader range of activities, which can be subsumed under the following three functions: provide funding liquidity, transform assets, and ameliorate the information problem between investors and borrowers.

By introducing the core literature around these functions, the paper discussed what makes banks 'special' versus other entities of the economy. The section also highlights implications of technology and Fintech innovations to the role of banks in the financial intermediation.

\section{Banks as liquidity providers}

The role of banks as liquidity providers has been studies by a large literature suggesting that one of the reasons for banks existence is to supply liquidity to borrowers and lenders (Diamond - Dybving, 1986; Gorton - Pennacchi, 1990; Lewis, 1992; Rajan, 1996; Holmström - Tirole, 1998; Kashyap et al., 2002; Gatev - Strahan, 2006; Diamond, 2007; Tirole et al., 2010).

Diamond and Dybvig (1986) suggest that an important role of banks is to create liquidity, thus banks fulfill valuable activities on both sides of their balance sheets by granting loans to borrowers and providing liquidity on demand to depositors. Banks usually fulfill their liquidity provision function by granting long-term and illiquid loans to borrowers by using short-term and liquid deposits. By offering these services jointly, banks can provide liquidity services to customers and investors who are uncertain about the timing of their future consumption need (Diamond - Dybving, 1986; Lewis, 1992). Holmström and Tirole (1998) argue that a key function of a financial intermediary is to provide liquidity in the form of loan commitments. Kashyap et al. (2002) also emphasize that banks provide liquidity through loan commitments or credit lines. Loan commitments can give a borrower the option to draw down their loan amount on demand during the period of the contract. These withdrawals are uncertain to the bank. From the perspectives of customers, loan commitments provide liquidity, like demand deposits, whenever they require liquidity unexpectedly.

Traditionally, the transformation service of creating liquidity is to be provided almost exclusively by banks, and, consequently, particularly importance has been at to preserve the ability of banks to create liquidity. Deposit insurance is considered the most effective measure to prevent runs without preventing banks from creating liquidity, and, consequently, bank policy issues should be considered in the context of deposit insurance (Diamond Dybving, 1986). It has been shown that deposit insurance enables banks to meet increased credit demand and syn- chronized draw-downs during episodes of market stress (Gatev - Strahan, 2006).

Liquidity provision, especially providing credit and payment services in the area most affected by Fintech competition. This area has attracted the most investment and companies to experiment and offer new technologies and type of services. Many firms are attempting to create their proprietary payment platforms or to compete in the provision of access to established payment systems with new technology or infrastructure. At the same time, alternative lending players are offering non-bank credit to different actors of the economy.

As Aaron et al. (2017) have highlighted, an important implication of the competition from Fintech players in the liquidity provision is that banks could reduce the amount of bank deposits and their credit to the economy. However, the likelihood will depend on the rate of adoption of the alternative means of liquidity and the reaction and response of banks. The rate of adoption of newer and more advanced technologies may be delayed by the notion that new form of liquidity provision platform require acceptance by both customers and merchants, a problem that has received attention in the literature (Camere et al., 2016; Arifovic et al., 2017).

\section{Banks as asset transformers}

Banks not only provide liquidity but they are doing it by transforming the different assets in their balance sheet. By grating loans and collecting deposits, banks provide the transformation of maturity, liquidity, and risk between their assets and liabilities. They simultaneously grant both borrowers with permanent or long-term capital and lenders with liquidity deposit for their asset holdings, deposit that liquid enough to be turned into cash at short notice. To manage this conflicting demand of lenders and borrowers, financial intermediaries such as banks transform the cash flow of firms into a form that lenders find desirable (Gurley - Shaw, 1960; Gorton - Pennacchi, 1990; Casu Girardone, 2006; Tirole et al., 2010).

Financial intermediaries also address the risks associated with maturity transformation by diversifying funding sources. Risk associated with transformation of default risk can be reduced by obtaining information on potential borrowers and selecting those that have the highest repayment potentials. In this regard, Buckle and Thompson (2004) point out that banks have advantage over direct lender in obtaining useful information on potential borrowers since most of these borrowers use banks' payment services.

Through their asset transformation activity banks also decrease transaction costs of channeling funds between borrowers and lenders, leading to a more efficient allocation of resources.

An important implication of Fintech advancement is the peer-to-peer lending models and the emergence of marketplace lending players. The core objective of these lending platforms is to channel savings from individuals and investors directly to borrowers, hence reducing the costs of intermediation (Yum et al., 2012; Balyuk, 2016). 
The fourth chapter of the paper discusses this role of marketplace lending players more broadly.

\section{Banks as information monitories}

The information monitoring and provision function of financial intermediaries is broadly discussed in the literature on information asymmetry, especially in cases when moral hazard and adverse selection problems are addressed.

In general, the role of banks can also be explained by their 'agent' function. As Jaffee and Russell (1976) and Stiglitz and Weiss (1981) argue banks have been the institutional solution to the problem of asymmetric information in the credit market between lenders and borrowers. Banks process information and monitor borrowers using specialized technologies. They act as delegated monitors and ensure that firms use the resources allocated to them and are able to mitigate asymmetric information resulting in adverse selection and moral hazard by screening and monitoring borrowers at reduced cost versus individual lenders (Diamond, 1984; Allen - Carletti, 2010).

Banks also have comparative advantage to other financial intermediaries (such as individual lenders or specialized firms, as lending providers) in information production because of economies of scale and scope, which reduce the cost of informational asymmetries. As a result, diversification decreases the cost of delegated monitoring to a financial intermediary and allows banks to provide monitoring service on a lower cost than monitoring done individually (Leland - Pyle, 1977; Bhattacharya - Thakor, 1993). In doing so, banks often establish long-term trust-based financial relationships with their clients, which may further mitigate the negative impacts of adverse selection and moral hazard on the resource allocation process (Mayer, 1988).

Furthermore, in the economy the quality of information is most cases difficult to collect therefore the distinction between good and bad information is not readily available Leland and Pyle (1977) argue that because of the lack of adequate information on quality, the price of information in general will reflect average quality. This will also result in a higher-than-average cost of searching for high-quality information. They argue that in the financial market these problems can be resolved by a bank which uses information to buy and hold assets in its portfolio. In this way, information becomes a private good and not transferable, thus providing an incentive to gather information.

Technology has significantly reshaping the information monitoring role of financial intermediaries. Many Fintech firms are active in information processing, exploiting the amount of information available. These business models usually exploit technology like big data and machine learning. New technologies have brought significant changes in methods to collect, present, and evaluate information. Search costs for credit information have been reduced, and the collection of credit assessment data has transformed covering much wider set of data. This has led to the potential decrease of asymmetric information problem in banking (Yan et al., 2015; He et al., 2017).

\section{The advantage of banks in financial intermediation versus other financial institutions}

The question arises whether non-bank financial and non-financial institutions can replace banks in their role of financial intermediation. While some does not distinguish the role of banks and non-bank financial intermediaries (Allen - Santomero, 1997), others highlight the uniqueness of banks versus others (Bhattacharya - Thakor, 1993; Rajan, 1996; Kashyap et al., 2002; Aaron et al., 2017). Banks have been considered to have important advantages over other financial institutions and non-bank market participants in providing various forms of liquidity services. This section aims to summarize the key arguments why banks have certain advantage compared to other market participants in the financial intermediation.

First, banks are the sole financial intermediaries who can offer the public with liquidity and payment services both through their deposit-taking and lending business. Rajan (1996) and Kashyap et al. (2002) emphasize banks' advantageous role in liquidity provision versus other financial intermediaries. They argue that the two core banking activities - taking in deposits on demand and originating loans - should be performed by financial institutions as both activities require an institution to come up with cash at short notice. Banks' advantage comes from the notion that by offering these services jointly banks can resolve the liquidity management problem that arises when loan commitments are drown down and immediacy is demanded on deposits. Both services require banks to hold balances of liquid assets to provide liquidity on demand to depositors as well as to credit line borrowers. Banks leverages synergy as they combine deposit-taking with loan commitments. They argue that banks have an advantage in providing liquidity because deposit withdrawals and loan commitment drawdowns are not highly correlated.

Second, scale and scope economics argument also requires that the two activities should be performed by the same institutions (Rajan, 1996; Walter, 2003; Aaron et al., 2017). Sources of scale and scope economies include information- technology related economies, risk transformation advantage, reputation and marketing related benefits, innovation related economies, and diversification benefits (Beck, 2001; Walter, 2003).

While new market entrants often scale up rapidly at lower cost than traditional players, exploring the advantages of scale and scope economies will determine the ability of banks to defend their competitive position from Fintech entrants (Boot, 2016). This is especially true for the risk transformation activity of banks. By pooling large funds, financial intermediaries reduce the risk of an investment to the investor. A financial intermediary needs a large fund of deposits and loans to reduce the risk of one particular single customer. By giving their customers products with stable distributions of cash-flows, financial intermediaries can reduce the costs of an investment for their customers (Allen - Santomero, 1997). The function of financial intermediaries as risk-pooling institutions is 
especially important in market segments with illiquid assets or long-term maturities. In these segments, the risk and the standard deviation of the returns on investment are very high. It requires high risk premium and a large pool of funds to compensate for this risk (Beck, 2001).

Third, as highlighted earlier, scale economics argument also applies for the information monitoring activity of banks. As argued by Leland and Pyle (1977) financial intermediaries can be seen as information sharing coalitions. Diamond (1984) later highlighted that these coalitions can achieve economies of scale by claiming that intermediaries who perform the monitoring are diversifying their portfolio and are bigger which allows them to finance a large number of debtors. Considering that diversification leads to the increase of the number of bank credits, the financial intermediaries of larger sizes is generating scale economies in the monitoring process as well.

\section{Fintech challenge for banks - Disintermediation on both side of the balance sheet?}

By the technological advancement, other financial and non-financial institutions besides banks became capable to provide financial services to the public. One may argue that the reduction of transaction costs caused by the internet have reduce the barriers to enter the market and eliminates some of the information asymmetries for financial intermediation and creates opportunity for new type of financial intermediaries and business models to emerge disintermediate some of the activities and function of traditional banks. Competition from non-bank players due to the internet is especially relevant for products which are standardized and have a low risk.

Although several Fintech players claim to challenge banks, there are two business models that gained share so far: online marketplace lenders aiming to disintermediate traditional banks in credit process and neo-banks providing deposit services for customers in a low-cost operating model.

The question, however, if these new players on the market are able to compete with banks and potentially replace or are they rather complementary to the existing financial intermediation activity of traditional banks. While the role of online marketplace lenders in the financial intermediation have been addressed by academia (see Yum et al., 2012; Kirby - Worner, 2014; Mills - McCarthy, 2014; Morse, 2015; Milne - Parboteeah, 2016; Balyuk, 2016; Hopstaken et al., 2016), neo-banks and their role and relationship with traditional financial institutions has not yet been addressed.

\section{Online marketplace lending}

Marketplace lending is a newly emerging segment of the financial services industry that leverages investment capital and operates data- and technology-driven online platforms to lend either directly or indirectly to retail consumers and small businesses. The segment initially emerged as a peer-to-peer lending, with companies giving consum- ers and individual investors the ability and the platform to find investment opportunities and provide financing to individual borrowers. As products and business models have evolved, the investor base for online marketplace lenders has expanded and today includes institutional investors, hedge fund, and financial institutions besides individual investors. In recognition of this shift in investor base, the market as a whole has evolved beyond a pure peer-to-peer model (Kirby - Worner, 2014; Mills - McCarthy, 2014).

The history of the online marketplace lending has begun in the United Kingdom with the lunch of Zopa in 2005. Since the launch of the platform, the market has experienced a significant global growth. Many platforms have been launched both in developed and developing countries, however countries show a different market evolution depending on their regulatory and market environment. (Table 1.)

\section{Exhibit 1}

\section{Evolution of online marketplace lending globally}

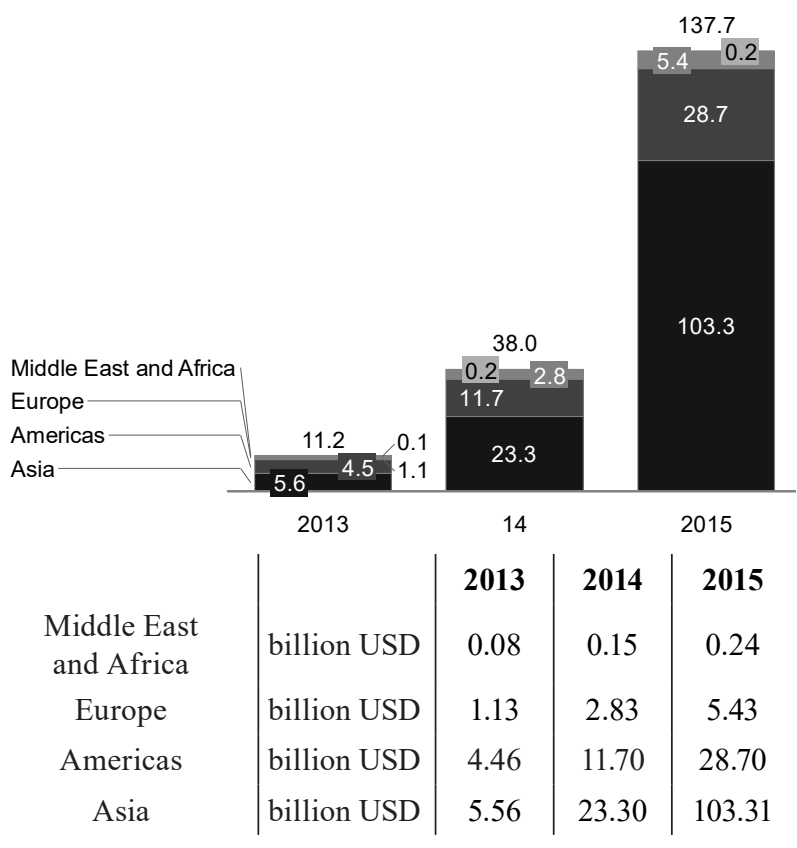

(Wardrop, et al., 2016) (Zhang, et al., 2017) (Zhang, et al., 2016) (Gravery, et al., 2017) (Ziegler, et al., 1017)

In Europe, United Kingdom is the most developed market in terms of online marketplace. By the end of 2015, the size of market reached USD 4.41 billion, accounting for $81 \%$ of the total European market (Zhang et al., 2016).

In the United States, it is estimated that marketplace lenders accounted for loan originations worth approximately USD 28.28 billion in 2015 with almost 16 million consumer having loans with alternative lending players in the USA (Ziegler et al., 1017; Wolf, 2017).

China's online marketplace lending sector has undergone an extremely rapid growth since the first platform gone live in 2007. The launch of PPDAI, the first online lending platform was followed by the emergence of several major platforms, including Hongling Capital, Renrendai and Lufax. The industry as a whole entered the "fast lane" 
and developed rapidly, with multifold increases across all main indicators such as the number of investors, borrowers, platforms and business turnover. While there is yet no verifiable industry-wide data on the volume of online marketplace lending in China, it is estimated that marketplace lending volume reached USD 102.19 million in 2015 with 2,595 online marketplace lenders on the market (Gravery et al., 2017; Morgan Stanley, 2015).

When it comes to the online marketplace lending players, the largest lender is Lending Club operating in the United States, which has granted loans of over USD 22 billion since its launch in 2011. Lending Club is operated by note-based business model for consumers. This is the most commonly used business model in the sector. To apply for credit, credit applicants need to register their credit needs and personal information on the Lending Club website. Lending Club assesses the credit applicant's creditworthiness and determines the applicant's risk rating using its proprietary credit rating system. Credit applicants are classified to different groups on their expected repayment risk. The interest rate applied is determined based on the risk classification of the applicant. Investors of Lending Club can choose which loan they wish to invest in, based on the information provided by the applicant, the size and risk rating of the loans. While the interest payable by the credit applicant cannot be influenced by the investors, they can decide what portion of the loan they wish to finance. When the full amount of the loan is collected, a designated bank grants the loan and sells a note to Lending Club at the amount of the loan. Lending Club then resells this note to its investors. Lending Club does not take any responsibility for repaying the loan, as the obligor of the note is the borrower. In the case of a potential default, the risk is borne by the investor.

Lending Club and the other online marketplace lenders compete with traditional banks in costs and services. Thanks to full-scale operation and the regulatory arbitrage resulting from indirect lending, they can operate with operating costs $300-400$ basis points lower than traditional banks. Hence even Lending Club, one of the largest and longest-established players on the market, has been in the red since its launch in 2011, which justifiably calls into question the sustainability of the business model (LendingClub, 2016; Molnar - Adam, 2017).

Online marketplace lending platforms offer a new form of intermediation by enabling the direct matching of lenders and borrowers. Albeit in early stage, online marketplace lenders have developed various business models, with one common characteristic: the platform only act an indirect intermediary between the funding source and the borrower. As a result, they do not take traditional credit risks and therefore are subject of fewer regulations than traditional financial credit provision institutions. This operating model allows them to operate with more capital efficiency and lower operating costs (Hopstaken et al., 2016).

Online marketplace lenders typically differ from each other according to the product type and their business model applied. Online marketplace lenders usually pro- vide a limited number of product types or show prevailing attention to a specific market segment. They are usually focusing on the less complex loan products, such as personal loans (e.g., Zopa, Prosper, Lending Club), student loans (e.g., SoFi), small business lending (e.g., First Circle, Kabbage), invoice discounting (e.g., The Receivables Exchange, Market Invoice), foreign exchange transactions (e.g., Currency Cloud, Currency Fair, Transferwise), real estate financing (e.g., Lending Home, Reality Mogul).

As commonly argued, online marketplace lenders bring innovation to credit disintermediation on two fronts. One is the launch of online platforms that allow matching borrowers and lenders directly. These platforms allow individual borrowers to request a loan online, and lenders to screen loan applications and decide how much to lend. Although the business model of indirect lending has already existed before, online marketplace lenders have created a public market for consumer debt, creating more transparency around demand and supply. A second technological innovation is the use of fully-automated algorithms to price and underwrite loans to lower screening and transaction costs.

Some argue that online marketplace lending platforms can disintermediate banks in the provision of credit (Morse, 2015; Balyuk, 2016). This is stemming from the notion that these online platforms adhere some of the activities of traditional financial intermediaries. Similar to banks, they are able to act as delegated monitors and to mitigate asymmetric information on the market. They are not just monitoring information, but claim to better reduce financing frictions in the consumer credit market than banks because information streams through several lending relationships. Given the marketplace lending credit process described above, these platforms can improve information as they are leveraging information from a divers set of institutional lenders, lenders that use different proprietary credit risk screening method. As Allen and Gale (1999) highlighted, public markets can be superior to financial intermediaries in providing funding because diversity of opinion is valuable when information is inexpensive. This may apply to online marketplace lenders as well. The combined information screening of different investors may mitigate asymmetric information problem by leveraging the wisdom of the crowd especially in customer segments where signals on creditworthiness of new borrowers are very limited (Yum et al., 2012; Balyuk, 2016).

This paper argues, however, that despite their role to mitigate information, the alternative models of online marketplace lending are rather complementary to, and not competitive with the traditional credit provision of financial institutions. There are three main reasons for that. First, online marketplace lending platforms may, in some extent, disintermediate banks in credit provision, but they cannot compete with banks in the provision of liquidity services. By offering deposit, payment and lending services jointly, banks can provide liquidity services to customers who are uncertain about the timing of their future consumption need. As such, banks are pooling liquidity 
that provide customers with insurance against idiosyncratic shocks that affect their consumption needs. Hence, customers can draw deposits on demand and have flexibility in their use of loan facilities. Customers are willing to accept lower rates of return on deposits higher costs of borrowing in return for these liquidity services. While some of the online marketplace lending platforms are offering liquidity services, the scope of these services is limited, mostly because they do not have access to central bank liquidity (Milne - Parboteeah, 2016).

Second, unlike banks, online marketplace lending platforms do not engage in maturity transformation. In theory, platforms do not allow investors to provide investment with a shorter maturity than the maturity of the credit refinanced. As an effect, online marketplace lenders are unable to intermediate between borrowers and investors with heterogeneous preferences. An alarming trend, however, that online marketplace lending platforms are more often allow maturity mismatch, and enable lenders to withdraw money more quickly than borrowers are required to repay loans. As Lord Adair Turner, former head of the Financial Services Authority in the United Kingdom, warned online marketplace lending may be the source of high systemic risk if the initial, simple peer-to-peer lending model is altered allowing complex product, long and complex distribution chains in which the same securities passed through multiple different links, and if securities with long underlying maturity can be re-financed by positions using shortterm money market borrowing (Turner, 2016).

Finally, loans provided by the online marketplace lender platforms are rather supplementary to bank loan in the high-risk borrower segments. Researches from countries with developed online marketplace lending sector have addressed this question. In Germany De Roure et al. (2016) and Blaseg and Koetter (2015) have found that previously neglected segments of the consumer credit market, such as high-risk consumers and those applying for small credit lines, as well as businesses facing lack of credit by banks are the potential borrowers of the new online marketplace lending platforms. Chaffee and Rapp (2012) have found in the U.S. that this form of lending has brought funding to individuals "that were underserved by the credit markets even prior to the retraction of those markets in 2008".

\section{Neo-banks}

The proliferation of internet services and the growing adoption of online and mobile channels among customers have fueled the entrance of new type of banks in the financial sector. The common characteristics of these companies that they adopted an internet-only strategy having little or even no branch system and relying on other, usually non-physical networks - mainly internet and mobile - to meet the majority of customers' transaction and financial service needs.

Hence, traditional banks are also embracing internet-focused strategy, some of the new intermediaries entering the financial sector, the so called neo-banks are adopting a fundamentally different operating model. Neobanks have started to operate in developed countries, es- pecially in United Kingdom and USA in the last couple of years. Neo-banks offer purely internet-based services for customers and putting accessibility in the heart of their service offering. They are called 'banks' as they synthesize the offering of traditional consumer bank products, such as current account, saving accounts, payment services and occasionally credit products. On the operations side, however, neo-banks appear to be very different from banks.

A key aspect of their operation is the absence bank license and partnership with other financial institutions. As these players have no bank license, they provide their financial products in partnership with one or several licensed financial institutions that provide back office, core banking, compliance, transaction processing, fraud and risk management along with the 'white-label' product. Neo-banks usually deliver only the services and not the products $^{1}$, receives fee income from customers and pays subscription fee for the partner banks.

As of today, neo-banks have a narrow range of product offerings with two different models evolving: One, the solely deposit and payment model where deposits are held by one partner bank (examples include Monese and Osper in the United Kingdom or Simple in the United States). Second, some of neo-banks offer both deposit, payment and credit products. In this case, the two products are under the management of different partner institutions (who are responsible for the credit assessment and underwriting) or the credit product is issued by the neo-bank itself that owes consumer credit license. Although neo-banks are new phenomena in financial intermediation, some of the players have already altered their business model and moved from the indirect intermediation model to direct intermediation by being granted of a banking license.

The core innovation of the neo-bank business model is that it removes risk and lowers regulatory requirements as it usually does not offer credit directly to customers. The indirect product model also simplifies operations through the lack of complex IT infrastructure and bureaucratic overhead. The lower operating costs allows these businesses to pass rent benefits to customer and as an effect, allows a lower price for services. Neo-banks are a completely new type of non-bank financial intermediaries, as they are gathering deposit - although indirectly - without former banking license.

One of the first neo-bank launched in Europe was the Germany-based N26 (previously known as Number26). It was initially launched in a neo-bank business model offering current account, payment and investment management for its customers. N26 have no physical branches, customer can manage all their banking products and services on an online or mobile platform. When launched N26 has no products, but operated in partnership with other financial institutions to offer all its services. Its deposit product was offered in partnership with Wirecard Bank, a bank with full-banking license. All N26 accounts was opened and held by Wirecard Bank and was responsible for fulfill-

1 One exception is Varo that offers deposit products managed by US Bancorp and gained lending. 
ment of all legal and regulatory requirements. N26 partnered with Transferwise, a peer-to-peer payment provider company to allow N26's customers transferring money overseas, as well as Vaamo, a German online investment management and robo-advisory company to allow N26 customer to invest into simple investment products. In July 2016 N26 received a banking license in Germany that changed indirect business model for bank to a direct model (N26, 2017).

Despite the internet-based business models, neo-banks have not reached significant customer number yet. Table 2. highlights the customer numbers of some of the largest neo-banks.

Exhibit 2

Launch year and customer numbers of neo-banks

\begin{tabular}{c|c|c} 
& Launch year & Customer number \\
\hline Atom Bank & 2016 & 17,000 \\
\hline Monzo & 2015 & 200,000 \\
\hline N26 & 2015 & 500,000 \\
\hline Revolut & 2015 & $1,000,000$ \\
\hline Tandem & 2015 & 100,000
\end{tabular}

The question this paper is addressing whether financial intermediation literature can explain the emergence and offer rational for the existence of these new type of nonbank financial intermediaries. Although there are some arguments that neo-banks are able to disintermediate the traditional banking model in some respects, the main argument of this paper is that neo-banks in theory are not substitutes of banks and can enhance the financial intermediation only under a few conditions.

Neo-banks aim in general is to embrace the technology-driven behavioral shifts and provide technology-driven banking services. Hence, the volume and market share that neo-banks have commanded so far in terms of customer numbers is small and as highlighted above, their offering is founded on basic services, mainly current and savings accounts. Nonetheless, their needs-oriented approach to customers, especially millennials, and their originality makes them worth consideration as potential competitors for the established banks.

First, in general, white-label intermediation model can create value and result in a more effective financial intermediation if the intermediary between the consumers and the product provider can lower transaction cost or monitor borrowers more effectively. In the neo-bank business model, neo-banks act as additional intermediaries for liquidity provisioning and monitoring between the bank and the borrowers. As asymmetric information problems in financial business requires an intermediary with a good reputation, neo-banks can improve intermediation efficiency only if they have good reputation or better expertise than traditional banks. Neo-banks value proposition is that they are able operate with an innovation agility that traditional banks are unable to provide, have a better understanding of today's technologies and are able to focus on narrow solutions to the exact needs of the customers. Therefore, they can act as a supplement to traditional banks to ensure early reaction to the changing customer behavior driven by technological change.

Second, it can be argued that neo-banks by leveraging internet-based business mode can significantly reduce the transaction cost. It is true that the most important single feature of the internet and business models embracing online and mobile technologies is the reduction of transaction costs. This will lead to enlarged markets and to an extended division of labor. As argued by Niehans (1983) in his paper on transaction cost innovation theory, the dominant factor of financial innovation is the reduction of transaction cost, and financial innovation is often the reaction to the advancement of technology which caused the transaction costs to decline. In the recent years, the reduction of communication costs significantly helped financial intermediaries to reach new markets and customers without building up an expensive network of branches (Corrocher, 2002; Chang, 2003; Sabi, 2014). However, transaction cost reduction of financial intermediation has been also been embraced by traditional banks as well, who introduced several online and mobile banking services for customers both in the developed and developing countries. Therefore, the reduction in transaction costs as an argument alone may not justify the existence of neo-banks.

Third, the delegated monitoring argument only holds for lending, an activity that only a few neo-banks are doing, if neo-banks can monitor borrowers more effectively and the cost of monitoring is higher than the rent paid by the depository bank to the neo-bank. But neo-banks, as newly launched startups, assumed to have neither better reputation, nor better expertise than banks.

Fourth, as neo-banks usually provide only deposit products to customers, they cannot compete with traditional, full-service banks in liquidity provision and asset transformation.

Furthermore, it is important to highlight that the neobank business model requires the stringent oversight of regulatory bodies. Even though these players are not licenced banking player, they can affect the financial stability. It is stemming from the notion that there is moral hazard issue if information monitoring mechanism is not mutual. Since neo-banks have no capital and customer deposits are insured by another institution they can be incentivized in risk-increasing strategies.

Despite claiming to act as a competitor for banks in financial intermediation, with their current business model, neo-banks are no competition, but rather a complementation to the role of banks in financial intermediation by reducing the transaction costs to deliver deposits. Their long-term existence is only justified if they can maintain the transaction cost advantage. However, recent improvements in information technology makes the acquisition of information easier for every actor, including banks and that can question the long-term sustainability of this business model. 


\section{Conclusion}

This paper discussed the role of new entrants in the financial market in the context of the financial intermediation literature. It focused on two particular segments of the Fintech sector: online marketplace lenders and neo-banks. Both segment has experienced significant media attention on the last few years. Online marketplace lenders in the lending market and neo-banks in the deposit market claim that they can superior financial services to customers than traditional banks. Their superior value proposition is based on the argument that they are able operate with an innovation agility that traditional banks are unable to provide, have a better understanding of today's technologies and are able to laser focus on narrow solutions to the exact needs of the customers.

The paper reviewed the role of these new players of the financial market in the context of the financial intermediation. By reviewing the literature on financial intermediation theory, the three main functions of banks in the financial intermediation of banking services have been introduced: provide funding liquidity, transform assets, and ameliorate the information problem between investors and borrowers. By introducing the core literature around these functions, the paper also highlighted what makes banks 'special' versus other financial intermediaries.

This paper argued that neither the online marketplace lending model, nor the neo-bank model are competitive, but rather supplementary to traditional banks. In case of online marketplace lending, although these players might be able to better reduce financing frictions in the credit market, but they cannot compete with banks in the provision of liquidity services and in asset transformation. Neobanks role can also be explained a complementary versus competitive market position in the context of financial intermediation theory.

\section{References}

Aaron, M. - Rivadeneyra, F. - Sohal, S. (2017): Fintech: Is this time different? A framework for assessing risks and opportunities for central banks. Ottawa: Bank of Canada

Allen, F. -Carletti, E. (2010): The roles of banks in financial systems. In: The Oxford Handbook of Banking. New York: Oxford University Press, p. 37-58.

Allen, F. - Gale, D. (1999): Diversity of opinion and financing new technologies. Journal of Financial Intermediation, Volume 8, p. 68-89.

Allen, F. - Santomero, A. M. (1997): The theory of financial intermediation. Journal of Banking \& Finance, 21(11-12), p. 1461-1485.

Arifovic, J. - Duffy, J. - Jiang, J. H. (2017): An experimental study of the adoption of a new payment methods. Bank of Canada Staff Working Paper, Issue 28

Balyuk, T. (2016): Financial Innovation and Borrowers: Evidence from Peer-to-Peer Lending. Toronto: Rotman School of Management Working Paper No. 2802220 .
Beck, H. (2001): Banking is essential, banks are not. The future of financial intermediation in the age of the Internet. Netnomics: Economic Research and Electronic Networking, 3(1), p. 7-22.

Bhattacharya, S. - Thakor, A. V. (1993): Contemporary banking theory. Journal of Financial Intermediation, p. 2-50.

Blaseg, D. - Koetter, M. (2015): Friend or foe? Crowdfunding versus credit when banks are stressed. Halle: Halle Institute for Economic Research Discussion Paper No. 8.

Boot, A. W. A. (2016): Understanding the Future of Banking: Scale \& Scope Economies, and Fintech. In: A. Demirgüç-Kunt - D. D. Evanoff - G. G. Kaufmann (eds.) (2016): The Future of Large Internationally Active Banks. Singapore: World Scientific Studies in International Economics, p. 429-447.

Buckle, M. J. - Thompson, J. (2004): The UK Financial System. Manchester: Manchester University Press

Camere, G. - Casari, M. - Bortolotti, S. (2016): An experiment on retail payments systems. Journal of Money, Credit and Banking, 48(2-3), p. 362-392.

Casu, B. - Girardone, C. (2006): Bank competition, concentration and efficiency in the single European market. The Manchester School, 74(4), p. 441-468.

Chaffee, E. C. - Rapp, G. C. (2012): Regulating online peer-to-peer lending in the aftermath of Dodd-Frank: In search of an evolving regulatory regime for an evolving industry. Washington \& Lee Law Review, Vol. 69, Issue 2

Chang, Y. T. (2003): Dynamics of banking technology adoption: an application to internet banking. Warwick economic research papers (No.664). Coventry: University of Warwick, Department of Economics

Corrocher, N. (2002): Does Internet banking substitute traditional banking? Empirical evidence from Italy. CESPRI Working Paper 8133.

De Roure, C. - Pelizzon, L. - Tasca, P. (2016): How Does P2P Lending Fit Into the Consumer Credit Market? Bundesbank Discussion Paper No. 30/2016.

Diamond, D. W. (1984): Financial intermediation and delegated monitoring. The Review of Economic Studies, Vol. 51, No. 3, p. 393-414.

Diamond, D. W. (2007): Banks and Liquidity Creation: A Simple Exposition of the Diamond-Dybvig Model. Economic Quarterly, 93(2), p. 189-200.

Diamond, D. W. - Dybving, P. H. (1986): Banking Theory, Deposit Insurance, and Bank Regulation. Journal of Bussiness, 59(1), p. 55-68.

Gatev, E. - Strahan, P. E. (2006): Banks' advantage in hedging liquidity risk: Theory and evidence from the commercial paper market. Journal of Finance, Volume 61, p. 867-892.

Gorton, G. - Pennacchi, G. (1990): Financial Intermediaries and Liquidity Creation. Journal of Finance, 45(1), p. $49-71$.

Gravery, K. et al. (2017): Cultivating Growth: The 2nd Asia Pacific Region Alternative Finance Industry Report, Cambridge: Cambridge Centre for Alternative Finance 
Greenbaum, S. - Thakor, A. (2007): Contemporary Financial Intermediation. Amsterdam: Elsevier

Gurley, J. G. - Shaw, E. S. (1960): Money in a theory of finance. Washington: Brookings Institution

He, D. et al. (2017): Fintech and Financial Services: Initial Considerations. IMF Staff Discussion Note, Issue 5

Holmström, B. - Tirole, J. (1998): Private and Public Supply of Liquidity. Journal of Political Economy, 106(1), p. 1-40.

Hopstaken, A. et al. (2016): When Finance Meets Internet: The Marketplace Lending Industry. HJCO Capital Partners Alternative Investment Reserach, January

Jaffee, D. M. - Russell, T. (1976): Imperfect Information, Uncertainty, and Credit Rationing. Quarterly Journal of Economics, Volume 90, Issue 4, p. 651-666.

Kashyap, A. K. - Rajan, R. - Stein, J. C. (2002): Banks as Liquidity Providers: An Explanation for the Coexistence of Lending and Deposit-Taking. Journal of Finance, 57(1), p. 33-73.

Kirby, E. - Worner, S. (2014): Crowd-funding: An infant industry growing fast. Staff Working Paper of the IOSCO Research Department

Leland, H. E. - Pyle, D. H. (1977): Informational Asymmetries, Financial Structure, and Financial Intermediation. Journal of Finance, 32(2), p. 371-387.

Lending Club (2016): Lending Club Statistics. [Online] Available at: https:/www.lendingclub.com/info/demand-and-credit-profile.action [Accessed 23 October 2016].

Lewis, M. K. (1992): Modern Banking in Theory and Practice. Revue Economiqué, 43(2), p. 203 - 277.

Mayer, C. (1988): New Issues in Corporate Finance. European Economic Review, 32(5), p. 1167-1183.

Mills, K. G. - McCarthy, B. (2014): The State of Small Business Lending: Credit Access during the Recovery and How Technology May Change the Game. Harvard Business School Working Paper, No. 15-004. Boston: Harvard Business School

Milne, A. - Parboteeah, P. (2016): The Business Models and Economics of Peer-to-Peer Lending. Brussels: European Credit Reserach Institute, Reserach Report No 17.

Molnar, J. - Adam, K. (2017): A FinTech-jelenség hatása - Radikális változás zajlik a pénzügyi szektorban? Hitelintézeti Szemle, 16(3), p. 32-50.

Morgan Stanley (2015): Global Marketplace Lending: Disruptive Innovation in Financials. New York: Morgan Stanely Blue Paper

Morse, A. (2015): Peer-to-Peer Crowdfunding: Information and the Potential for Disruption in Consumer Lending. NBER Working Paper No. 20899.

N26 (2017): N26 company webiste. [Online] Available at: https://n26.com [Accessed 30 November 2017].
Niehans, J. (1983): Financial innovation, multinational banking, and monetary policy. Journal of Banking \& Finance, 7(4), p. 537-551.

Rajan, R. G. (1996): Why Banks have a Future: Toward a New Theory of Commercial Banking. Journal of Applied Corporate Finance, 9(2), p. 114-128.

Rochet, J.-C. - Freixas, X. (2008): Microeconomics of Banking. Boston: MIT Press

Sabi, H. M. (2014): Research Trends in the Diffusion of Internet Banking in Developing Countries. Journal of Internet Banking and Commerce, 19(2)

Stiglitz, J. E. - Weiss, A (1981): Credit Rationing in Markets with Imperfect Information. The American Economic Review, Volume 71, Issue 3, p. 393-410.

Tirole, J. - Dewatripont, M. - Rochet, J.-C. (2010): Balancing the Banks: Global lessons from the financial crisis. Princeton: Princeton University Press

Turner, A. (2016): Speech by Lord Adair Turner to LendIT Europe 2016. Available at: https://p2pfa.org.uk/ lord-adair-turners-speech-to-lendit-europe-2016/ [Accessed 30 November 2017]

Walter, I. (2003): Strategies in financial services, the shareholders, and the system: Is bigger and broader better? NYU Working Paper, Issue FIN-02-025

Wardrop, R. et al. (2016): Breaking New Ground: The Americas Alternative Finance Benchmarking Report. Cambridge: Cambridge Alternative Finance Center

Wolf, R. (2017): P2P Loans are "Predatory," Have Delinquency Characteristics of pre-2007 Subprime Mortgages, Could Impact Financial Stability. Cleveland Fed. [Online] Available at: https://wolfstreet. com/2017/11/13/p2p-loans-are-predatory-have-delinquency-characteristics-of-pre-2007-subprime-mortgages-could-impact-financial-stability-cleveland-fed/ [Accessed 29 November 2017].

Yan, J. - Yu, W. - Zhao, L. J. (2015): How signaling and search costs affect information asymmetry in P2P lending: the economics of big data. Financial Innovation, 1(19), p. 1-11.

Yum, H. - Lee, B. - Chae, M. (2012): From the wisdom of crowds to my own judgment in microfinance through online peer-to-peer lending platforms. Electronic Commerce Reserach and Applications , 11(5), p. 469483.

Zhang, B. et al. (2017): The Africa and Middle East: Alternative Financing Benchmarking Report, Cambridge: Cambridge Centre for Alternative Finance

Zhang, B. et al. (2016): Sustaining Momentum: The 2nd European Alternative Finance Industry Report, Cambridge: Cambridge Alternative Finance Center

Ziegler, T. et al. (2017): Hitting Stride: The 2nd Americas Alternative Finance Industry Report. Cambridge: Cambridge Centre for Alternative Finance 